\title{
Interleukin-11: Stimulation In Vivo and In Vitro by Respiratory Viruses and Induction of Airways Hyperresponsiveness
}

\author{
Oskar Einarsson, ${ }^{\star \ddagger}$ Gregory P. Geba, ${ }^{\star}$ Zhou Zhu, ${ }^{\star \ddagger}$ Marie Landry, ${ }^{\ddagger \S}$ and Jack A. Elias ${ }^{\star \ddagger}$ \\ ${ }^{*}$ Yale University School of Medicine, Section of Pulmonary and Critical Care Medicine, Department of Internal Medicine, New Haven, \\ Connecticut 06520; ${ }^{\ddagger}$ Research Service, West Haven Veterans Administration Medical Center, West Haven, Connecticut 06516; and \\ ${ }^{\S}$ Yale University School of Medicine, Department of Laboratory Medicine, New Haven, Connecticut 06510
}

\begin{abstract}
To address the role of IL-11 in viral airways dysfunction, we determined whether infectious agents that exacerbate asthma stimulate stromal cell IL-11 production, determined whether IL-11 could be detected at sites of viral infection and evaluated the effects of IL-11 on airway physiology. Respiratory syncytial virus (RSV), parainfluenza virus type 3 (PIV3), and rhinovirus (RV) 14 were potent stimulators while cytomegalovirus and adenovirus only weakly stimulated and herpes simplex virus type 2 and bacteria did not stimulate IL-11 elaboration. IL-11 was not detected or barely detected in nasal aspirates from children without, but was detected in aspirates from children with viral upper respiratory tract infections. The levels of IL-11 were highest in patients with clinically detectable wheezing. IL-11 also caused nonspecific airways hyperresponsiveness in BALB/c mice. These studies demonstrate that three major causes of viral-induced asthma, RSV, RV, and PIV, in contrast to other viruses and bacteria, share the ability to induce stromal cell IL-11 production. They also demonstrate that IL-11 can be detected in vivo during viral respiratory infections, that the presence of IL-11 correlates with clinical bronchospasm and that IL-11 is a potent inducer of airways hyperresponsiveness. IL-11 may be an important mediator in viral airways disorders. (J. Clin. Invest. 1996. 97:915-924.) Key words: IL-6-type cytokines • asthma • respiratory syncytial virus $\bullet$ parainfluenza virus $\bullet$ rhinovirus
\end{abstract}

\section{Introduction}

Asthma is a major medical problem in the United States affecting between 9 and 12 million people (1). Epidemiologic studies of this disorder demonstrated a close temporal relationship between respiratory viral infections and asthmatic exacerbations (reviewed in references 2-4). As a result, viruses are felt to be one of the most common causes of asthma in children and a major cause of asthma in adults. These studies have also demonstrated that only specific respiratory infectious agents cause asthmatic exacerbations. Respiratory syncytial vi-

Address correspondence to Jack A. Elias, M.D., Yale University School of Medicine, Section of Pulmonary and Critical Care Medicine, Department of Internal Medicine, 333 Cedar Street, 105 LCI, New Haven, CT 06520. Phone: 203-785-4163; FAX: 203-785-3826.

Received for publication 7 April 1995 and accepted in revised form 22 November 1995.

J. Clin. Invest.

(C) The American Society for Clinical Investigation, Inc.

0021-9738/96/02/0915/10 \$2.00

Volume 97, Number 4, February 1996, 915-924 rus $(\mathrm{RSV}){ }^{1}$, parainfluenza virus (PIV), and rhinovirus (RV) commonly cause exacerbations, adenovirus (Ad) causes asthmatic exacerbations less often and cytomegalovirus (CMV), herpes simplex virus (HSV), and bacteria are not associated with asthmatic flares (2-4). Viruses exacerbate asthma via complex multi-mechanistic processes that involve epithelial injury and the induction and/or alteration of local inflammation $(2,3,5-8)$. Virus-induced cytokine production $(7,9)$ and neural dysregulation with decreased beta-adrenergic and enhanced cholinergic and tachykinin responses $(3,10-12)$ are well documented. However, the basis of this viral specificity, the mechanisms by which viruses induce local inflammation and the way(s) viral inflammation alters airway physiology are poorly understood.

Interleukin-11 (IL-11) is a newly appreciated pleiotropic cytokine (reviewed in references 13-15). It was initially discovered as a fibroblast-derived molecule that stimulated the proliferation of "IL-6-dependent" T1165 cells in the presence of neutralizing antibodies against IL-6 (16). It is now classified as an IL-6-type cytokine based on functional similarities of IL-11 and IL-6 and the shared use of gp130 molecules in their receptor complexes $(13-15,17)$. IL-11 and IL-6 appear, however, to play different roles in biology since they do not have significant sequence homology, have only partially overlapping functional profiles and are regulated differently at sites of production $(13-15,18,19)$. IL-6 dysregulation has been associated with and/or implicated in the pathogenesis of a wide variety of disorders (reviewed in reference 20) including asthma $(21,22)$. In contrast, IL-11 dysregulation is not well documented in any human disease or disease model.

IL-11 is an extremely cationic cytokine (pI 11.7) with the ability to activate $\mathrm{B}$ cells via a $\mathrm{T}$ cell-dependent mechanism (23), synergize with IL-4 (24), and c-kit ligand (25) and regulate neural phenotype (26). These properties are particularly intriguing in regard to asthma since cations such as eosinophil major basic protein (MBP) (pI 10.9) $(27,28)$ and T lymphocytes (particularly $\mathrm{Th}_{2}$ cells) (29) play important roles in asthmatic inflammation, IL-4 is an important regulator of IgE production and $\mathrm{Th}_{2}$ lymphocyte development $(30,31)$, c-kit ligand regulates mast cell development (32) and members of the IL6-type cytokine family induce cholinergic neural differentiation and augment tachykinin production (26). Our studies have demonstrated that human lung fibroblasts and alveolar and airway epithelial-like cells produce IL-11 in response to inflammatory cytokines (19), histamine (33), and eosinophil

1. Abbreviations used in this paper: Ad4, adenovirus type 4; AHR, airways hyperresponsiveness; CMV, cytomegalovirus; HSV, herpes simplex virus; LIF, leukemia inhibitory factor; MBP, major basic protein; PIV, parainfluenza virus; RSV, respiratory syncytial virus; RV, rhinovirus. 
MBP (34). Importantly, they also demonstrated that RSV is an extremely potent inducer of stromal cell IL-11 elaboration (9). These observations led us to hypothesize that IL-11 is an important mediator in the pathogenesis of virus-induced asthma. To test this hypothesis, studies were undertaken to determine if: (a) viruses and other infectious agents that do and do not exacerbate asthma induce stromal cell IL-11 production; (b) IL-11 can be detected at sites of viral respiratory tract infection; and (c) IL-11 can mediate physiologic alterations compatible with the asthmatic state. These studies demonstrate a correlation between the ability of a virus (infectious agent) to stimulate stromal cell IL-11 production in vitro and its known ability to cause asthmatic exacerbations in vivo. Specifically, they show that, in contrast to a variety of other pneumotropic viruses and bacteria, RSV, PIV type 3 (PIV3) and RV are potent stimulators of IL-11 elaboration. They also demonstrate that IL-11 can be found in the nasal secretions of children with viral upper respiratory tract infections, that nasal IL-11 correlates with the presence of clinically detected wheezing and that IL-11 induces a state of AHR in murine airways.

\section{Methods}

\section{Antibodies, cytokines, and cells}

Antibodies and cytokines. The monoclonal antiviral antibodies that were used in these studies were obtained from a variety of sources. Monoclonal antibodies to PIV3 and adenovirus were from Bartels Diagnostics (Bellevue, WA); RSV, Dako (Carpenteria, CA); HSV-2, Syva (Palo Alto, CA); and CMV immediate early antigen, Dupont NEN (Boston, MA). Monospecific polyclonal rabbit antiserum against recombinant human IL-11 and mouse IgG monoclonal antibodies 11h3/15.6.13 and 11h3/19.6.1 against human rIL-11 were obtained from Drs. Edward Alderman and Paul Schendel (Genetics Institute, Cambridge, MA). Recombinant human IL-11 (specific activity $\sim 1.8 \times 10^{6} \mathrm{U} / \mathrm{ml}$ in a T1165 proliferation assay $(19,23)$ was also obtained from Dr. Paul Schendel (Genetics Institute).

Cell culture. Cell cultures in roller tubes, shell vials and Petri dishes were used in these experiments and yielded comparable results. The roller tubes and shell vial cultures containing MRC-5 fetal lung fibroblasts and A549 alveolar epithelial type II-like cells were obtained from BioWhittaker (Walkersville, MD) and were maintained in Eagles minimal essential medium (EMEM) with $2 \%$ fetal calf serum (FCS). MRC-5 and A549 cells for use in stationary cell culture systems were obtained from American Type Culture Collection (Rockville, MD) and were grown to confluence in 100-mm Petri dishes in Dulbecco's Modified Eagle Medium (DME) supplemented with $10 \%$ FCS as previously described $(9,19)$.

\section{Viral stock preparation}

Pilot experiments were performed using viruses recently isolated in the Clinical Virology Laboratory at Yale-New Haven Hospital. Subsequent experiments were performed using characterized virus strains obtained from the American Type Culture Collection. The viruses that were employed included: RSV Long and A2 strains, PIV3 C 243 strain, RV type 14 (RV14) strain 1059, RV type 1A (RV1A), Ad type 4, RI67 strain, HSV type 2 (HSV-2) MS strain, and CMV AD169 strain. Viral stocks were prepared by infection of sensitive cell systems with a low input multiplicity of infection (MOI). Hep-2 cells were used for RSV, rhesus monkey kidney epithelial cells (RhMK cells) were used for PIV3, MRC-5 cells were employed for CMV and RV14, and A549 cells were employed for HSV-2 and Ad4. When infection was advanced, cells supernatants were harvested, cells disrupted by freezing and thawing, or for CMV by vortexing with glass beads, and debris pelleted by low speed centrifugation. Aliquots of clarified supernatants were frozen at $-70^{\circ} \mathrm{C}$ in $10 \%$ DMSO.
Infectivity titers of stock viruses were determined by inoculation of serial dilutions into sensitive cell systems as indicated above. Virus growth was detected by observation of typical cytopathic effects (CPE) or hemadsorption with a $0.5 \%$ solution of guinea pig red blood cells, followed by immunofluorescence staining of infected cell monolayers as previously described by our laboratories $(35,36)$.

\section{Cell infection and supernatant preparation}

On the day of infection, cell culture medium was aspirated and cultures were inoculated with virus stock, at a MOI of 1.0-3.0. After a 1-h adsorption, the cell monolayers were rinsed, maintenance medium with $2 \%$ FCS was introduced and the cells were incubated for up to $6 \mathrm{~d}$. At designated time points the supernatants were removed, clarified by low speed centrifugation and frozen at $-70^{\circ} \mathrm{C}$ until evaluated. Viral replication was documented by: $(a)$ assessing CPE, $(b)$ assessing hemadsorption in cultures infected with PIV3, and $(c)$ immunofluorescence staining as previously described $(35,36)$. Initial experiments were performed using roller drums to enhance viral growth. Subsequent experiments using stationary cultures demonstrated similar results.

Supernatants from bacterially infected cells were also prepared. Stocks of Staphylococcus aureus and Streptococcus pneumoniae were obtained from Dr. Keith Joiner (Yale University). Aliquots were added to the cultures at a cell:bacteria ratio of $\sim 1$ to 3 and the incubations carried out at $37^{\circ} \mathrm{C}$ in $5 \% \mathrm{CO}_{2}$ and air for up to $6 \mathrm{~d}$. At the end of these incubation periods supernatants were prepared as described above.

\section{Nasal aspirates}

To determine if IL-11 could be detected at sites of in vivo viral infection we quantitated the levels of IL-11 in pediatric nasal aspirates. These samples were obtained over a 4-mo period by the patient's primary care physicians and were submitted to the Clinical Virology Laboratory at Yale-New Haven Hospital for RSV isolation or viral
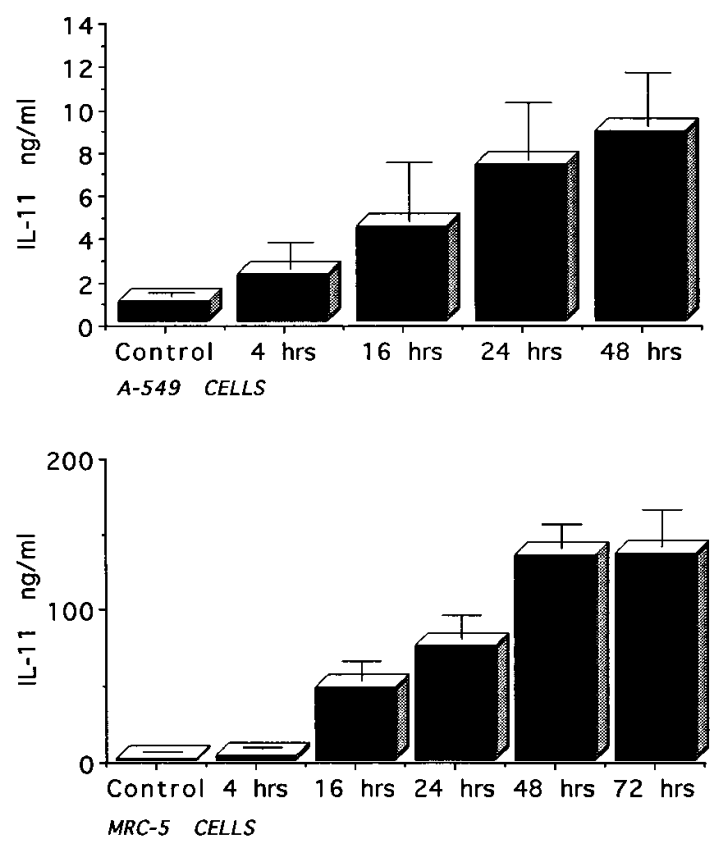

Figure 1. RSV stimulation of lung stromal cell IL-11 elaboration. Uninfected (control) and RSV infected A549 cells (upper panel) and MRC-5 cells (lower panel) were incubated for the noted periods of time. The IL-11 in the resulting cell supernatants was evaluated by ELISA. The control values are the highest levels of IL-11 noted during the incubation of the uninfected cells. All values represent the mean \pm SEM of five experiments. 
antigen detection. In general, 1-3 $\mathrm{ml}$ volumes were obtained using normal saline. After aliquots were removed for clinical analysis, the remaining samples were stored at $-70^{\circ} \mathrm{C}$. IL- 11 levels were measured by ELISA (see below). Clinical information was obtained via retrospective chart reviews. The patients were classified as manifesting or not manifesting upper respiratory tract infection symptomatology based on the presence (or absence) of fever, cough and nasal congestion. Chart reviews were also used to classify the patients as manifesting or not manifesting reactive airways disease based on the presence or absence of clinically apparent wheezing. All protocols were reviewed and approved by the Human Investigation Committee of Yale University School of Medicine.

\section{Quantification of IL-11}

IL-11 was quantified using ELISA techniques previously described by our laboratory $(9,19)$. Monoclonal antibody $11 \mathrm{~h} 3 / 19.6 .1$ was resuspended in carbonate buffer to achieve a concentration of $1 \mu \mathrm{g} / \mathrm{ml}$ and $100 \mu \mathrm{l}$ aliquots were used to coat the surface of microtiter plates (Nunc-Immuno Plate; Nunc, Naperville, IL). After an overnight incubation, the plates were washed in PBS-Tween buffer, blocked with $300 \mu \mathrm{l}$ of $1 \%$ BSA, incubated for $1 \mathrm{~h}$ with IL-11 standards or dilutions of test supernatant and then rewashed and incubated for $1 \mathrm{~h}$ with a 1:10,000 dilution of biotinylated $\mathrm{mAb} 11 \mathrm{~h} 3 / 15.6 .13$. After an additional washing step, avidin horseradish peroxidase (Vector Laboratories, Burlingame, CA) was added for $1 \mathrm{~h}$ and color substrate was added after an additional washing. Color development was allowed to proceed until stopped with aliquots of $\mathrm{H}_{2} \mathrm{SO}_{4}$ and O.D. at A490 was measured. This assay detects levels of IL-11 as low as $0.05-0.1 \mathrm{ng} / \mathrm{ml}$ and does not cross-react to a detectable degree with IL-6, IL- $1 \alpha$, IL$1 \beta$, IL-7, TGF- $\beta_{1}$, leukemia inhibitory factor (LIF), hepatocyte growth factor (HGF), and TNF. It also does not cross react significantly with eosinophil major basic protein (a gift from Dr. Steven Ackerman, Beth Israel Hospital, Boston, MA).

\section{Detection of IL-11 $m R N A$}

Total cellular RNA was extracted from uninfected and infected MRC-5 and A549 monolayers using acid guanidinium thiocyanatephenol-chloroform extraction as previously described $(9,19)$. Equal $10-\mu \mathrm{g}$ aliquots of total cellular RNA from each experimental condition were size fractionated by electrophoresis through $1 \%$ agarose/ $17 \%$ formaldehyde gels, transferred to nylon membranes and hybridized with ${ }^{32} \mathrm{P}$-labeled cDNA probes. Clone $\mathrm{pHulL}-11 / \mathrm{PMT}$, a 1250-bp IL-11 cDNA in the EcoRI site of the vector PXM was a gift from Dr. Paul Schendel (Genetics Institute).

\section{Characterization of the effects of IL-11 on murine airway physiology and pathology}

IL-11 challenge. After receiving light ether anesthesia, $100 \mu \mathrm{l}$ of rIL11 or vehicle control was applied to the nostrils of 10-12-wk-old BALB/c mice (Jackson Laboratories, Bar Harbor, ME) and subsequently inhaled into their lungs. Previous work from our laboratories has demonstrated that the tracking dye methylene blue is successfully

\section{A}
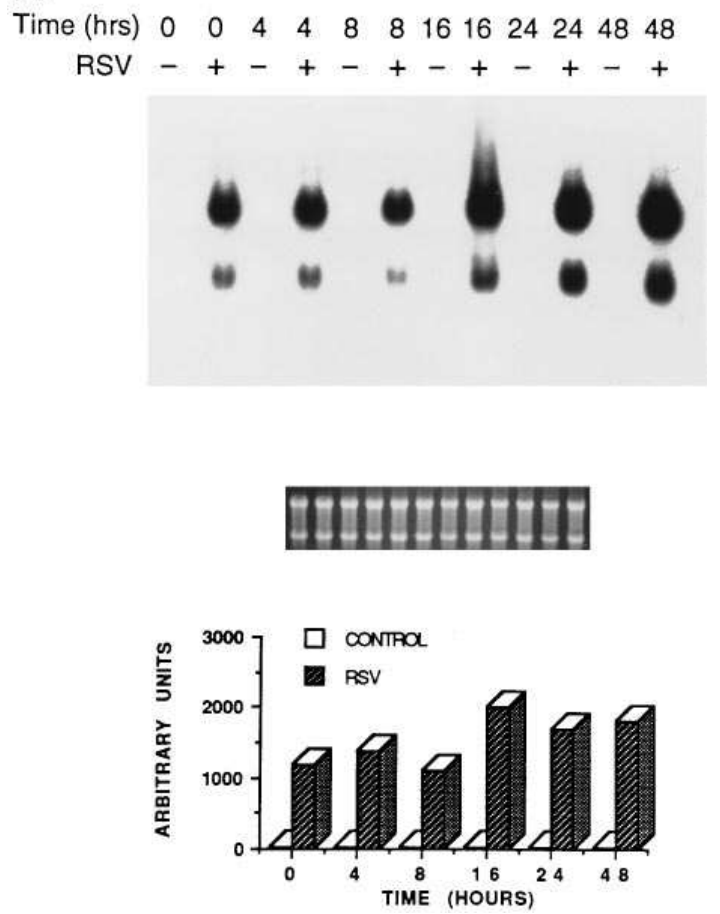

B

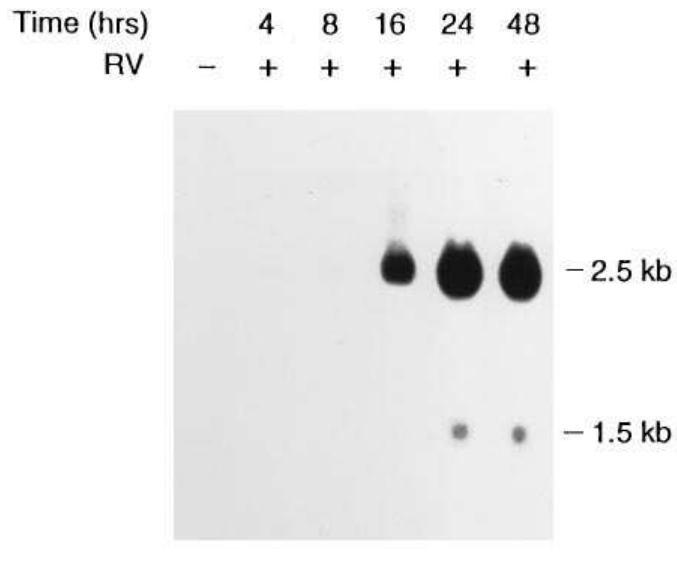

IIIIII

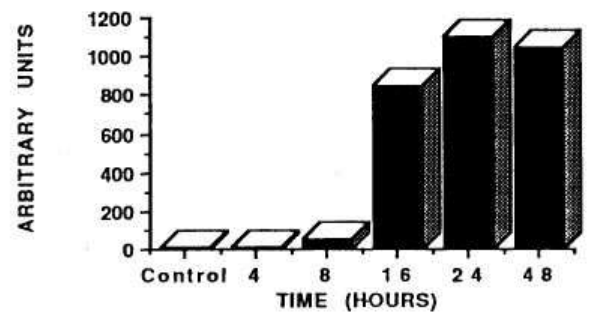

Figure 2. Stimulation of IL-11 mRNA in human lung stromal cells. Human lung stromal cells were infected with virus at an MOI of 3 . After adsorption for 1 hour, the cells were rinsed and incubated in appropriate maintenance medium with $2 \%$ FCS. The levels of IL- 11 mRNA in these cells at varying time points after infection were evaluated as described in Methods. $A$ illustrates the effects of RSV on IL- 11 mRNA in MRC-5 lung fibroblasts. $B$ illustrates the effects of RV14 on the IL-11 mRNA accumulation in A549 cells. In each panel IL-11 mRNA is at the top, ethidium bromide loading controls are in the center and the densitometric analysis of the mRNA is illustrated at the bottom of the figure. In this and other densitometric evaluations the 2 IL-11 mRNA transcripts were evaluated separately and then summated. 

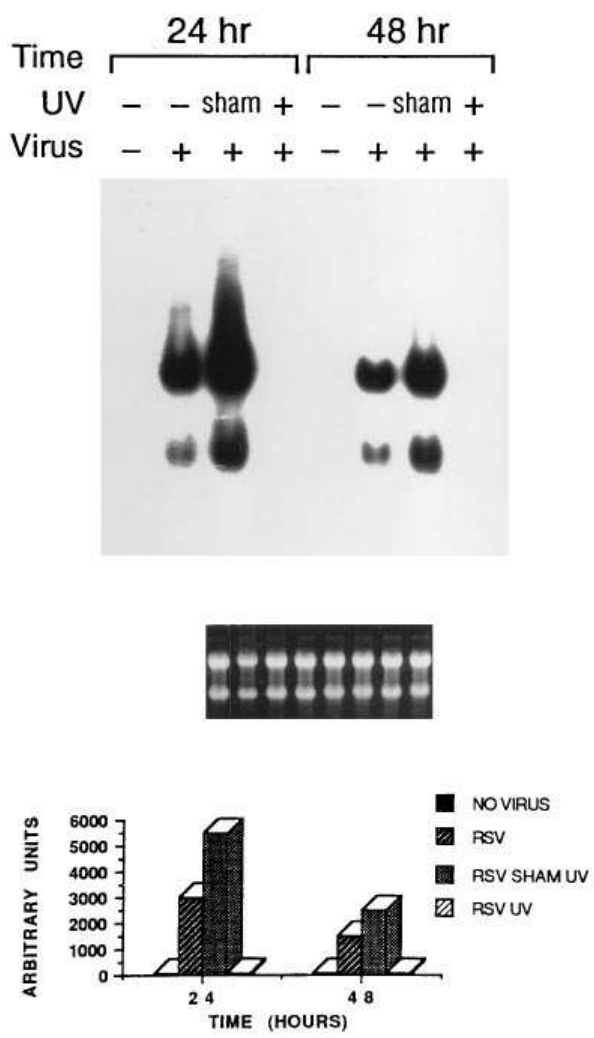

Figure 3. Effect of UV exposure on RSV stimulation of IL-11 mRNA accumulation in MRC-5 lung fibroblasts. MRC-5 lung fibroblasts were uninfected or infected with RSV $(\mathrm{MOI}=3)$. After viral adsorption for $1 \mathrm{~h}$, the cells were rinsed and incubated in maintenance medium with $2 \%$ FCS. The amount of IL-11 mRNA in these cells was evaluated 24 and $48 \mathrm{~h}$ after infection. RSV was used without modification, after UV inactivation or after sham UV exposure (RSV sham UV). The IL-11 mRNA is at the top, the ethidium bromide loading controls are in the middle and the densitometric analysis of the IL-11 mRNA is at the bottom of the figure.

deposited in the lung using this technique. In confirmation of this we also demonstrated that IL-11 could be detected by ELISA in the bronchoalveolar lavage (BAL) fluid, but not the nasal washings, of these animals within minutes and for up to $24 \mathrm{~h}$ after rIL-11 administration.

Physiologic evaluation. $24 \mathrm{~h}$ after IL-11 challenge mice were anesthetized by intraperitoneal injection of pentobarbital $(90 \mathrm{mg} / \mathrm{kg})$ and tracheostomized with an 18-gauge angiocatheter (Baxter Scientific, McGraw Park, IL). Airway resistance was then measured using the modifications of the techniques of Martin et al. (37) described previously by our laboratories (38). In these assessments, changes in the lung volume of anesthetized and tracheostomized mice were measured plethysmographically by determining pressure in a plexiglass chamber using an in line microswitch pressure transducer. Flow was measured by differentiation of the volume signal, and transpulmonary pressure was determined by a second microswitch pressure transducer placed in line with the plethysmograph and an animal ventilator. Resistance was then calculated using the method of Amdur and Mead (39). Resistance of the tracheostomy catheter was eliminated and baseline measurements of pulmonary resistance were obtained by ventilating the mouse in the plethysmograph at volumes of $0.4 \mathrm{ml}$ at a rate of 150 breaths/minute which was previously shown to produce normal arterial blood gases (37). Each mouse was studied at baseline. Bronchial hyperreactivity was then determined by methacholine challenge as described previously (38). Increasing concentra- tions of methacholine in PBS were administered by nebulization (20 $1-\mathrm{ml}$ breaths), and pulmonary resistance was calculated precisely $30 \mathrm{~s}$ later. Stepwise increases in methacholine dose were then given until the pulmonary resistance, in comparison with the baseline level, had at least doubled. The data are expressed as the provocative challenge $100\left(\mathrm{PC}_{100}\right)$, the dose of methacholine at which pulmonary resistance was $100 \%$ above baseline level.

Histologic evaluation. Ten 12-wk-old BALB/c mice were challenged with rIL-11 or vehicle control and allowed to recover for 24$48 \mathrm{~h}$. They were then killed by cervical dislocation, their chests opened by median stenotomy and the vascular tree perfused with calcium, magnesium free phosphate buffered saline (PBS) through the right heart. The heart, lungs and trachea were then removed en block and the lungs were fixed with $10 \%$ formalin and paraffin embedded. Hematoxylin and eosin stains were obtained in the Department of Pathology at Yale University School of Medicine.

\section{$B A L$ histamine measurements}

Animals were challenged with rIL-11 or vehicle control and $15 \mathrm{~min}$ to $48 \mathrm{~h}$ later were killed and their lungs removed as described above. They were then intubated and BAL was performed with three $0.5 \mathrm{ml}$ PBS washings. The levels of histamine in the BAL fluid were assessed using an enzyme immunoassay kit (Immunotech International, Westbrook, ME) as per the instructions provided by the manufacturer.

\section{Statistical methods}

Unless otherwise stated, values are expressed as the mean \pm standard error of the mean (SEM) and 95\% confidence intervals (CI). Differences in cytokine levels between patient groups were evaluated by nonparametric methods using the Mann-Whitney U test. Differences in airways resistance and methacholine responsiveness were also evaluated using the Mann-Whitney $U$ test. Calculations were performed using the StatView 4.01 (Abacus Concepts, Berkeley, CA) statistical analysis program for the Macintosh.

\section{Results}

Stimulation of IL-11 production by respiratory infectious agents. Uninfected lung stromal cells produced levels of IL-11 that were at or near the limits of sensitivity of our assay. As previously reported (9), RSV stimulated IL-11 protein production in a time-dependent fashion (Fig. 1). Similar effects were seen with both RSV strains that were employed (Long and A2 Strains) (data not shown). To determine if the ability to stimulate IL-11 production is a unique property of RSV we determined whether other pneumotropic viruses and infectious agents also stimulate stromal cell IL-11 elaboration. To accomplish this, A549 and MRC-5 cultures were infected with RSV, PIV3, RV14, RV1A, CMV, Ad4, HSV-2, or bacteria and IL-11 production was quantitated. As shown in Table I, RSV, PIV3 and RV14 were potent stimulators of IL-11 protein production. RV1A was similarly effective in stimulating IL-11 elaboration (Table II). In all cases, these stimulatory effects appeared to be, at least partially, pretranslationally mediated since viral-induced alterations in IL-11 protein elaboration were associated with comparable increases in IL-11 mRNA accumulation (Fig. 2 and data not shown). The stimulatory effects also appeared to be due to the viral infection since they were not appreciated with ultraviolet light inactivated virus and could not be reproduced with endotoxin $(0.1-10 \mu \mathrm{g} / \mathrm{ml})$ (Table III, Fig. 3 and data not shown). In contrast, CMV and Ad4 only weakly stimulated and HSV-2, Streptococcus pneumoniae and Staphylococcus aureus did not induce IL-11 production by these cells (Table I and data not shown). The find- 


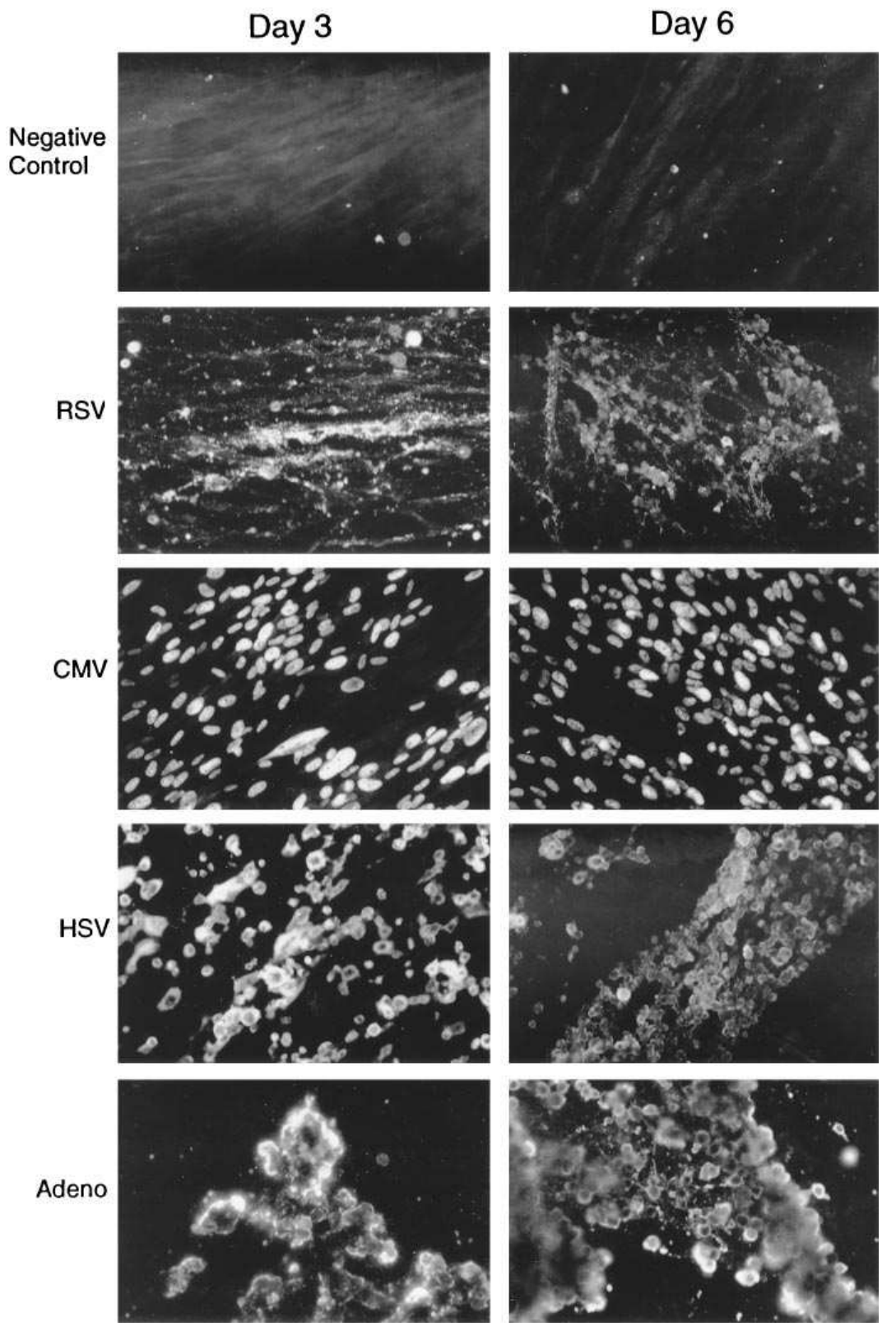

Figure 4. Demonstration of viral antigens in MRC-5 lung fibroblasts. Uninfected and virus infected fibroblasts were incubated for 3 or $6 \mathrm{~d}$ in maintenance medium with $2 \%$ FCS. Cytopathic effects and the presence of viral antigens were evaluated as described in Methods. ing that HSV-2, Ad4 and CMV did not effectively stimulate IL-11 production could not be attributed to the inability of these viruses to infect our cultures since they caused readily detectable cytopathic changes in the cell monolayers and viral antigens were easily detected in infected cells (Fig. 4). These studies demonstrate that the ability to stimulate stromal cell IL-11 production is not a general property of all pulmonary infectious agents. Instead, it appears to be at least partially specific for RSV, PIV3, and rhinovirus.

Detection of IL-11 in nasal secretions. To determine if respiratory virus stimulation of IL-11 production in vitro is relevant to the in vivo state, studies were undertaken to determine if IL-11 could be detected in the nasal secretions from patients with and without upper respiratory tract infections. To accomplish this, we quantitated the IL-11 in pediatric nasal aspirates sent for virologic evaluation to the Clinical Virology Laboratory at Yale-New Haven Hospital. A total of 42 samples from
39 children aged 1 wk to 30 mo were evaluated. 31 of the 42 samples were from children with symptoms compatible with a viral upper respiratory tract infection and viruses and/or viral antigens were detected in the aspirates of 21 of these children. Viruses were not cultured and viral antigen was detected in the secretions of only one of the asymptomatic children. The symptomatic and asymptomatic children did not differ in their ages or comorbid diseases. The results of the IL-11 measurements are illustrated in Figs. 5 and 6. They demonstrate that IL-11 was undetectable or present in very small quantities in the samples from patients lacking upper respiratory tract infection symptomatology $(0.115 \pm 0.022,95 \% \mathrm{CI}=0.065$ to 0.164$)$. In contrast, 22 of 31 samples from patients with clinical upper respiratory tract infections had demonstrable nasal aspirate IL-11 levels $(0.650 \pm 0.176,95 \% \mathrm{CI}=0.291$ to $1.009 ; P<0.001$, Mann-Whitney U test) (Fig. 5). Wheezing was detected only in children with clinical upper respiratory tract infections. Impor- 
Table I. Viral Stimulation of IL-11 Production by A549 and MRC-5 Cells

\begin{tabular}{|c|c|c|c|c|c|}
\hline \multirow[b]{2}{*}{ Cell line* } & \multirow[b]{2}{*}{ Virus* } & \multicolumn{2}{|c|}{ Day 3} & \multicolumn{2}{|c|}{ Day 6} \\
\hline & & IL-11* & $\mathrm{CPE}^{\S}$ & IL-11 & $\mathrm{CPE}^{\S}$ \\
\hline \multirow[t]{7}{*}{ MRC-5 } & Control & 1.35 & 0 & 1.10 & 0 \\
\hline & RSV & 116.31 & $4+$ & 124.71 & $4+$ \\
\hline & RV14 & 101.01 & $4+$ & 78.63 & $4+$ \\
\hline & PIV3 & 48.93 & $3+$ & 77.11 & $4+$ \\
\hline & HSV-2 & 0.07 & $4+$ & 0.24 & $4+$ \\
\hline & Ad4 & 1.86 & $4+$ & 1.89 & $4+$ \\
\hline & CMV & 3.86 & $4+$ & 5.29 & $4+$ \\
\hline \multirow[t]{7}{*}{ A549 } & Control & 0.55 & 0 & 0.80 & 0 \\
\hline & RSV & 3.93 & $1+$ & 3.71 & $4+$ \\
\hline & RV14 & 6.39 & $1+$ & 3.84 & $1+$ \\
\hline & PIV3 & 3.18 & $1+$ & 3.10 & $3+$ \\
\hline & HSV-2 & 0.61 & $4+$ & 0.65 & $4+$ \\
\hline & Ad4 & 0.88 & $3+$ & 0.70 & $4+$ \\
\hline & CMV & 0.38 & $1+$ & 0.42 & $1+$ \\
\hline
\end{tabular}

* MRC-5 or A549 cells were incubated for 3 or 6 d uninfected (control) and after infection with the noted viruses at a MOI of $3 .{ }^{\ddagger}$ IL- 11 concentration in $\mathrm{ng} / \mathrm{ml}$. Values represent the means of duplicate determinations that were within $10 \%$ of each other. ${ }^{\S}$ Cytopathic effects assessed via phase contrast microscopy on a scale from 0 (none) to $4+$.

tantly, the levels of IL-11 in the secretions from symptomatic patients with clinically detectable wheezing (reactive airways disease) (RAD) (0.861 $\pm 0.234,95 \% \mathrm{CI}=0.374$ to 1.348$)$ were also significantly higher than the levels in the secretions from patients without detectable bronchospasm $(0.179 \pm 0.041,95 \%$ $\mathrm{CI}=0.085$ to $0.272 ; P<0.008$ Mann-Whitney $\mathrm{U}$ test) (Fig. 6). Interestingly, three patients had two nasal aspirates performed 5-17 d apart. The IL-11 levels from the patient whose symptoms and wheezing resolved during this interval normalized, the IL-11 levels from the patient with persistent bronchospasm remained elevated and the IL-11 levels from the patient that developed bronchospasm during this interval rose (data not shown). These studies demonstrate that, in contrast to controls, IL-11 is detectable in the nasal secretions from children with viral upper respiratory tract infections and highlight an association between the presence of IL-11 and clinically apparent bronchospasm.

Table II. RV14 And RV1A Stimulation of MRC-5 Cell IL-11 Production

\begin{tabular}{lr}
\hline Virus* & IL-11* \\
\hline Control & 2.34 \\
RV14 & 57.89 \\
RV1A & 43.12
\end{tabular}

* MRC-5 cells were incubated for $48 \mathrm{~h}$ uninfected (control) and after infection with RV14 or RV1A at a MOI $=3$. ${ }^{\ddagger}$ Peak IL-11 concentration$\mathrm{ng} / \mathrm{ml}$. Values represent means of triplicates that were within $10 \%$ of each other.
Table III. RSV Stimulation of MRC-5 IL-11 Production: Effect of $U V$ Inactivation

\begin{tabular}{|c|c|}
\hline Virus* & IL-11* \\
\hline Control & 0.250 \\
\hline RSV & 59.80 \\
\hline RSV-Sham UV & 66.90 \\
\hline RSV-UV & 3.41 \\
\hline
\end{tabular}

* MRC-5 fibroblasts were incubated for $24 \mathrm{~h}$ uninfected (control) and after infection with RSV (MOI = 3). RSV was used without modification (RSV), after ultraviolet inactivation (RSV-UV) or after sham UV expose (RSV-Sham UV). ${ }^{\ddagger} \mathrm{IL}-11 \mathrm{ng} / \mathrm{ml}$.

Effect of IL-11 on airway physiology. The demonstrations that RSV, PIV3 and RV are major stimulators of lung stromal cell IL-11 production, that exaggerated levels of IL-11 can be detected in the nasal secretions of children with upper respiratory tract infections and that the levels of nasal IL-11 were highest in patients with clinical apparent wheezing led us to hypothesize that IL-11 plays a role in the abnormal physiology seen in viral airways disorders. To address this hypothesis, recombinant IL-11 was instilled into mouse airways and its effect on airway physiology evaluated. By itself, IL-11 did not cause bronchospasm since the baseline airways resistance of vehicle treated $\left(0.37 \pm 0.019 \mathrm{~cm} \mathrm{H}_{2} \mathrm{O} /\right.$ second $)$ and recombinant IL-11 treated animals $\left(0.33 \pm 0.14 \mathrm{~cm} \mathrm{H}_{2} \mathrm{O} /\right.$ second $)$ did not differ significantly $(P=0.14$, Mann-Whitney $\mathrm{U}$ test $)$. As demonstrated in Fig. 7, IL-11-treated animals did, however, manifest a marked increase in methacholine sensitivity. Twenty four hours after IL-11 inhalation, the mice that received rIL-11 required a 50-100-fold lower dose of methacholine to achieve a

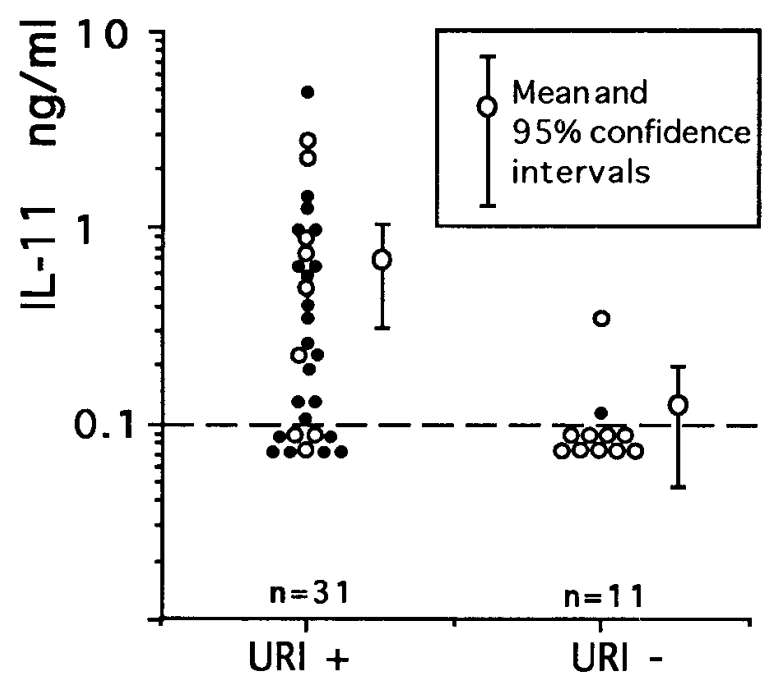

Figure 5. Demonstration of the levels of IL-11 protein in the nasal secretions from children with $(+)$ and without $(-)$ upper respiratory tract infection (URI) symptomatology. Each point represents an individual determination. The closed circles represent samples that contained virus or viral antigens. The open circle represent samples that did not contain virus or viral antigens. The lower limit of detectability with this assay $(\sim 100$ picograms $/ \mathrm{ml})$ is illustrated by the dashed line. The means and $95 \%$ confidence intervals for these evaluations are illustrated to the right of each column. 


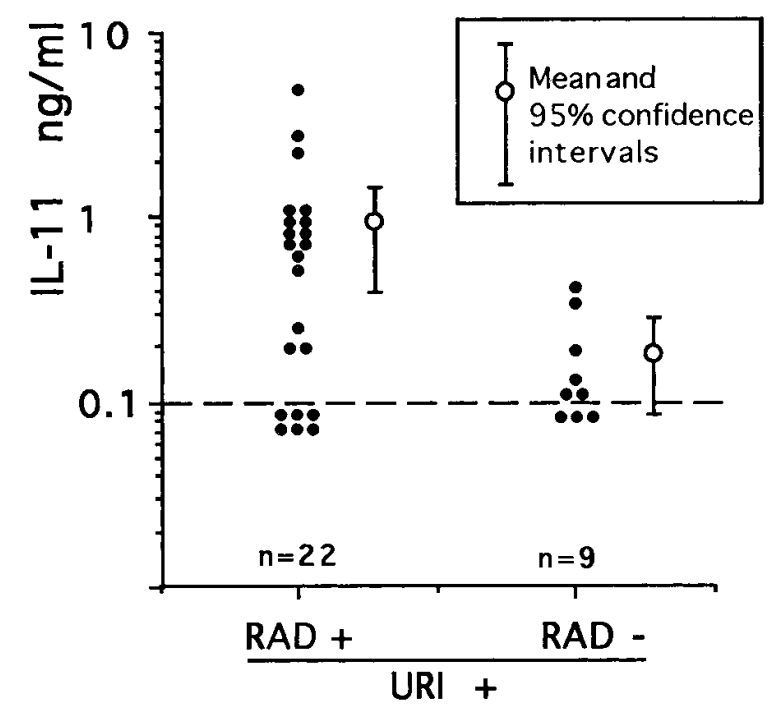

Figure 6. Demonstration of the levels of IL-11 in the nasal aspirates from children with upper respiratory tract infection symptomatology with (+) and without $(-)$ clinical bronchospasm (reactive airways disease) (RAD). Each point represents an individual determination. The lower limit of sensitivity of the assay is illustrated with the dashed line. The means and $95 \%$ confidence intervals for each group are illustrated to the right of each column.

$100 \%$ increase in airways resistance (Provocative Challenge $\left.100\left[\mathrm{PC}_{100}\right]\right)$ than animals that received the vehicle control (log $\mathrm{PC}_{100} 0.549 \pm 0.131$ vs. $2.662 \pm 0.172 ; P=0.008$, Mann-Whitney $\mathrm{U}$ test). Interestingly, significant quantities of histamine and significant differences in the BAL histamine content of rIL-11 and control challenged animals were not noted at all of the time points that were assessed. This was readily apparent $24 \mathrm{~h}$ after IL-11 administration when AHR is prominently noted but differences in histamine content are not $(21.0 \pm 2.9 \mathrm{nM}$ [IL11 challenged] versus $23.3 \pm 0.8 \mathrm{nM}$ [controls], $P=0.50)$. These studies demonstrate that rIL-11 is a potent stimulator of nonspecific airways hyperresponsiveness and suggest that this induction is not mediated by IL-11-induced histamine elaboration.

Effect of IL-11 on pulmonary pathology. To determine if IL-11-induced alterations in airway physiology were associated with IL-11-induced histologic abnormalities, we compared the pathologic features of animals that received rIL-11 and vehicle control. As seen in Fig. 8, rIL-11-treated animals manifest a mild patchy inflammatory response in which large areas of normal lung and small areas of lung with peribroncheolar and perivascular mononuclear cells were juxtaposed. Epithelial desquamation was not noted in IL-11 challenged animals and mononuclear infiltrates were not seen in the vehicle treated animals. Thus, IL-11 is a mild inducer of respiratory inflammation in this system.

\section{Discussion}

Clinicians have long been aware of the association between respiratory infections and asthmatic exacerbations. Epidemiologic studies have refined this appreciation by demonstrating that only specific infectious agents are strongly associated with asthmatic flairs. In infants and young children exacerbations are most commonly caused by RSV and PIV, whereas RV and coronavirus predominate in older children and adults (2-4).

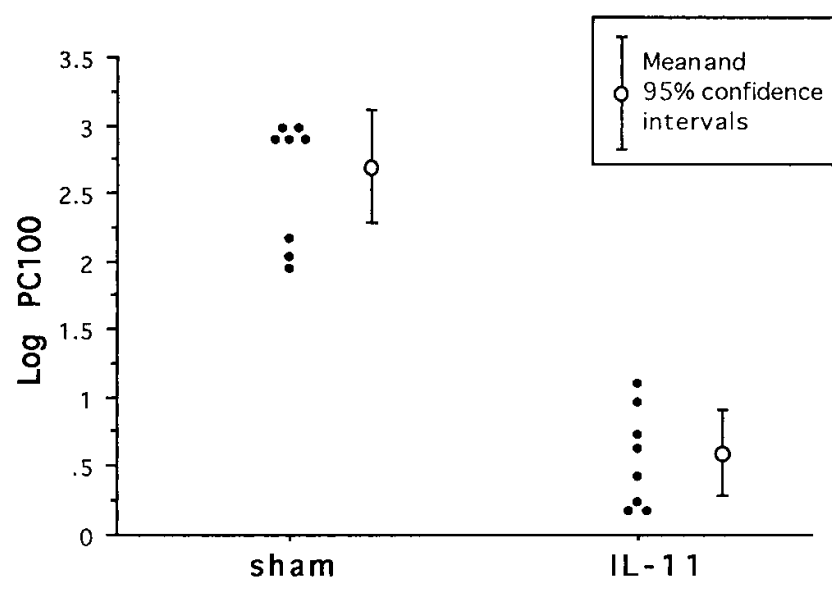

Figure 7. Demonstration of the effect of IL-11 on the methacholine sensitivity of the murine lung. BALB/c mice aspirated IL-11 $(10 \mu \mathrm{g})$ or appropriate vehicle control (sham) into their airways under light anesthesia. $24 \mathrm{~h}$ later their sensitivity to methacholine was evaluated by determining the dose of methacholine required to increase airways resistance by $100 \%$ (provocative challenge $100 ; \mathrm{PC} 100$ ). The mean values and $95 \%$ confidence intervals for each group are illustrated to the right of each column.

Adenovirus induces asthmatic exacerbations less often, CMV and HSV-2 have not been associated with asthmatic flairs and bacterial infections do not appear to be important causes of asthmatic deterioration (2-4). In keeping with the inflammatory nature of the asthmatic diathesis, it has been assumed that the infectious agents that cause asthmatic worsening alter airway inflammation in some common fashion. To date, however, there is little understanding of the common processes that link RSV, PIV, and RV in causing these flairs. Based on its biologic properties and production by RSV infected (9) lung stromal cells, we hypothesized that IL-11 might play a role in the pathogenesis of virus-induced airways dysfunction. To test this hypothesis, we determined whether infectious agents that exacerbate asthma in vivo stimulate IL-11 production in vitro. We also determined if IL-11 could be appreciated at sites of in vivo viral infection and whether IL-11 could induce any of the physiologic abnormalities characteristic of the asthmatic diathesis. Our studies demonstrate an impressive correlation between the ability of an infectious agent to stimulate IL-11 production in vitro and its known ability to cause asthmatic exacerbations in vivo. We found that three of the most common causes of viral-induced asthma (2-4), RSV, PIV, and RV, in contrast to a variety of other viruses and bacteria, share the ability to impressively stimulate stromal cell IL-11 elaboration. In addition, our studies demonstrate that exaggerated levels of IL-11 can be detected in the nasal secretions of children with viral upper respiratory tract infections, that the presence of nasal IL-11 correlates with clinically apparent wheezing and that a single dose of IL-11 causes AHR in mice. These observations demonstrate that IL-11 is produced in vitro and in vivo during specific viral infections and provide a mechanistic explanation for the AHR that is characteristically seen in viral-induced airways disorders. They also support the notion that a variety of respiratory viruses can cause asthmatic exacerbations via a common mechanism and suggest that the induction of IL-11 production may be one such shared pathway.

To determine if viruses stimulate IL-11 production in vivo, 

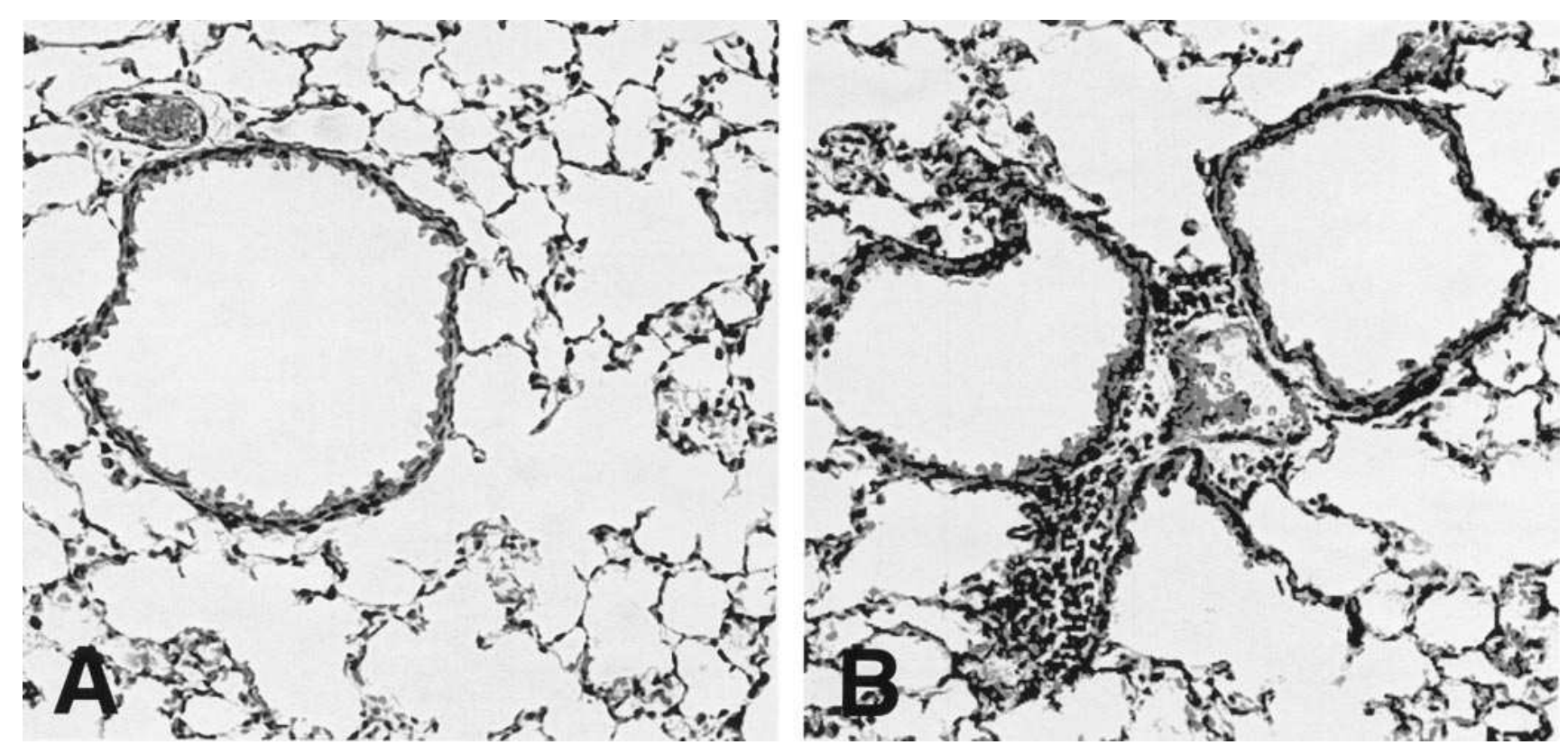

Figure 8. Demonstration of the effect of IL-11 on the histology of the murine lung. BALB/c mice aspirated rIL-11 (10 $\mu \mathrm{g})(B)$ or vehicle control $(A)$ into their airways under light anesthesia. $24 \mathrm{~h}$ later they were killed and their lungs were inflated, fixed, and subjected to $\mathrm{H} \& \mathrm{E}$ evaluation.

we measured the IL-11 levels in pediatric nasal aspirates that had been sent to our Clinical Virology Laboratory for standard clinical evaluations. These studies demonstrated that, in contrast to controls, IL-11 is detectable in the secretions from children with upper respiratory tract infections. The majority of these children had documented viral infections. In a significant number of cases, however, elevated levels of IL-11 were noted and viral infection was not documented. In interpreting these results, it is important to note that comprehensive viral evaluations were not performed. Instead, the evaluation was limited and dictated by the clinical concerns of the primary care physicians. Epidemiologic studies have demonstrated that viruses are the most common cause of upper respiratory tract infections in this setting $(7,40)$ and our data has demonstrated that Staphylococcus aureus and Streptococcus pneumoniae are not effective stimulators of IL-11 production. In keeping with these findings, we believe it is likely that the symptomatic children whose secretions contained IL-11 but not virus or viral antigen, also had viral infections and that these infections would have been documented with more extensive viral evaluations. We can not, however, rule out the possibility that non-viral causes of upper respiratory tract infection symptomatology such as mycoplasma also have the ability to stimulate IL-11 production.

A cardinal feature of asthma is the exaggerated bronchospastic response of the asthmatic airway to antigen and nonspecific agents such as methacholine, histamine and cold air $(41,42)$. Inflammation with the release of mediators from inflammatory cells is now thought to be the cause of this AHR (42). In spite of its importance, the inflammatory events that mediate asthmatic AHR are poorly understood. The limited information that is available suggests that, under appropriate circumstances, a number of cytokines including IL-1 (43), TNF (44), IL-5 (45), and IL-2 (46) can contribute to asthmatic physiology. Our studies add to this body of data by demonstrating that IL-11 has the ability to induce AHR in vivo. They also demonstrate that IL-11 is a weak inducer of pulmonary inflammation. We were intrigued, however, at the contrast between the impressive AHR and mild inflammatory response induced by IL-11. This suggests that IL-11 may not induce AHR solely via its ability to generate local tissue inflammation. Superficially, this would appear to conflict with current concepts of the pathogenesis of AHR. This speculation is in accord, however, with studies in humans and animals $(38,47-49)$ that demonstrate a dissociation between AHR and inflammation and with studies that demonstrate that under appropriate circumstances, IL-11 can augment $(13,14,23)$ and/or inhibit tissue inflammation and injury (50).

Virus-induced asthmatic exacerbations are characterized by overt bronchospasm and AHR which can persist for weeks after the resolution of the viral infection (2-4). Our demonstration that viruses stimulate IL-11 production in vivo and in vitro and that IL-11 induces AHR implicates IL-11 in the pathogenesis of the AHR seen with respiratory viral infections. IL-11 did not, however, cause overt bronchospasm in the mouse airway. This suggests that inflammatory mediators other than IL-11 are involved in the generation of this physiologic abnormality or that a different dose, kinetic or location of IL-11 administration is required to allow IL-11-induced bronchospasm to be appreciated.

An association between upper airway inflammation and AHR has been appreciated for years (49). The mechanism of this interaction is, however, poorly understood. Postnasal drip with the aspiration of inflammatory moieties, mediator absorption via the vascular compartment and a nasobronchial neural reflex have all been proposed as possible pathogenic pathways for this association $(49,51)$. In our studies, IL-11 was placed in the nostrils of lightly anesthetized animals and aspirated into their lungs. Thus, the AHR induced by IL-11 can be postulated to be the result of its lower respiratory tract or its nasal effects. We do not believe, however, that nasal effects play a major role in this induction because IL-11 was readily 
detectable in the BAL fluid, but not in the nasal washings of these animals immediately and for a period of time after IL-11 administration. In addition, we have also noted that AHR is a readily apparent feature of transgenic animals in which the Clara cell $10 \mathrm{kDa}$ protein $(\mathrm{CC} 10)$ promoter is used to target the expression of IL-11 to the mouse airway (W.L. Tang and J.A. Elias, unpublished observation).

In keeping with its relatively recent discovery, our knowledge of the physiologic and pathophysiologic effects of IL-11 is limited. In this manuscript we demonstrate that exaggerated levels of IL-11 can be detected in humans at sites of viral upper respiratory tract infections and that IL-11 induces AHR in the mouse lung. These are the first studies to demonstrate human IL-11 in vivo and directly implicate IL-11 in disease pathogenesis. The mechanism(s) by which IL-11 mediates its airway effects is poorly understood. There are, however, at least four possibilities that deserve mention. First, IL-11 is a T celldependent B cell stimulator (23). These lymphocyte effects could contribute to the inflammatory processes in the asthmatic airway. Second, IL-11 is an extremely cationic molecule (pI 11.7). In fact, it is more cationic than eosinophil MBP (pI 10.9). Cations such as MBP induce bronchospasm, AHR and mediator release and cause epithelial desquamation $(27,28)$. Third, IL-11 can synergize with stem cell factor (25) and IL-4 (24) in biologic systems. Since stem cell factor regulates mast cell proliferation and degranulation (32) and IL-4 regulates IgE production and $\mathrm{Th}_{2}$ lymphocyte development $(30,31)$, an interaction between these cytokines could contribute to the mast cell and lymphocyte abnormalities characteristic of the asthmatic diathesis. Lastly, IL-11, IL-6, LIF, ciliary neurotropic factor and oncostatin $\mathrm{M}$ have recently been grouped together as the IL-6-type cytokines. This group of cytokines is also called the neurokines based on their ability to regulate neural phenotype (26). LIF is the prototype of this group. It promotes neuronal survival, causes noradrenergic sympathetic neurons to take on a cholinergic phenotype and induces the production of tachykinins like substance-P $(26,52)$. IL-11 regulates the same set of genes in sympathetic neurons as LIF (26). Enhanced cholinergic function and tachykinin excess are well documented in viral-induced asthma (10-12). It is appealing to hypothesize that these abnormalities are due, in part, to IL-6-type cytokines such as IL-11 since this would provide an inflammatory explanation for this important feature of viralinduced asthma. Additional investigation will be required to determine the extent to which charge, receptor binding, lymphocyte activation and neural alterations contribute to IL-11induced AHR.

The mechanism(s) by which viruses stimulate stromal cell cytokine elaboration are poorly understood. These processes, however, may be initiated by virus binding to specific cell surface viral receptors. The cell surface receptors for the rhinoviruses are well defined. Approximately $85 \%$ of RV serotypes, including RV14, bind to and enter cells using cell surface intercellular adhesion molecule-1 (ICAM-1) (53). Others, including $\mathrm{RV} 1 \mathrm{~A}$, are in the minor receptor group. They do not bind ICAM-1 and instead bind the LDL receptor and related proteins (54). Our studies demonstrate that RV14 and RV1A are equally potent inducers of IL-11 elaboration by the stromal cell lines that were employed. Thus, rhinoviruses can induce stromal cell IL-11 elaboration via ICAM-1-independent pathways. If RV14 and RV1A stimulate IL-11 production via common mechanisms, these commonalties exist at a post-receptor level.
Inflammation has long been considered the province of marrow-derived cells such as $\mathrm{T}$ cells, monocytes and macrophages with stromal cells being considered only as producers of matrix molecules and components of the tissue scaffolding. It is becoming increasingly apparent, however, that the resident sessile cells in the lung, such as fibroblasts and epithelial cells, are also important contributors to tissue inflammation. This has been well documented in studies from this and other laboratories demonstrating that stromal cells, under appropriate circumstances, express HLA antigens and produce reactive oxygen species, prostaglandins, complement components and a wide variety of cytokines $(21,55)$. Asthma is now regarded as a chronic inflammatory disorder and fibroblast, myofibroblast and epithelial activation are well described features of the asthmatic airway. Our studies demonstrate for the first time that IL-11 may play a role in the pathogenesis of this process. IL-11 is the prototypical stromal cell-derived cytokine since it has not been demonstrated to be produced by monocytes, macrophages or lymphocytes (13-16). Thus, its presence at sites of viral infection likely represents local stromal cell activation and can be considered further evidence for an important role for stromal cells in the pathogenesis of virus-exacerbated airway disorders.

In summary, our studies demonstrate an intriguing association between the ability of respiratory pathogens to induce IL-11 production in vitro and their known ability to cause asthmatic exacerbations in vivo. Specifically, we have demonstrated that three of the most common viral precipitants of asthma, RSV, PIV, and RV, in contrast to a variety of other infectious agents, have the ability to strongly stimulate stromal cell IL-11 elaboration. We have also demonstrated that IL-11 can be detected in humans at sites of viral upper respiratory tract infections, that the presence of IL-11 correlates with clinically apparent wheezing and that IL-11 is a potent inducer of AHR in the murine lung. These studies suggest that IL-11 contributes to the pathogenesis of virus-induced airway disorders such as asthma and that the ability of an infectious agent to stimulate IL-11 production may be an important determinant of its ability to precipitate an asthmatic deterioration.

\section{Acknowledgments}

The authors wish to thank the investigators and the institutions that provided the reagents that were used, Drs. Anuradha Ray, Prabir Ray, Debra Tristram, and Robert Welliver for their helpful discussions, Mr. Emanuel Lerner of the Biostatistics Service of the West Haven Veterans Administration Medical Center Research Service, Mrs. Sandra Cohen and Carole Holm, R.N. for their expert technical and clinical assistance and Ms. Kathleen Bertier for her excellent secretarial assistance.

This work was supported by National Institutes of Health (NIH) grants HL-36708, AI-34953, and HL-54989 and Veterans Administration Merit Review Funding (J. A. Elias), and NIH grant K08-HL03226 (G. P. Geba).

\section{References}

1. Weiss, K.B., P.J. Gergen, and T.A. Hodgson. 1992. An economic evaluation of asthma in the United States. N. Engl. J. Med. 326:862-866.

2. Björnsdottir, U.S., and W.W. Busse. 1992. Respiratory infections and asthma. Clin. Allergy 76:895-915.

3. Stark, J.M., and F.M. Graziano. 1995. Lower Airway Response to Viruses. In Asthma and Rhinitis. W.W. Busse, and S.T. Holgate, editors. Blackwell Scientific Publications, Boston, MA. 1229-1243.

4. Pattemore, P.K., S.L. Johnston, and P.G. Bardin. 1992. Viruses as precip- 
itants of asthma symptoms. I. Epidemiology. Clin. Exp. Allergy. 22:325-336.

5. McIntosh, K., and R.M. Chanock. 1990. Respiratory Syncytial Virus. In Virology. 2nd edition. B.N. Fields, and D.M. Knipe, editors. Raven Press, Ltd., New York, NY. 1045-1072.

6. Alwan, W.H., F.M. Record, and P.J.M. Openshaw. 1993. Phenotypic and functional characterization of $\mathrm{T}$ cell lines for individual respiratory syncytial virus proteins. J. Immunol. 150:5211-5218.

7. Noah, T.L., F.W. Henderson, I.A. Wortman, R.B. Devlin, J. Handy, H.S. Koren, and S. Becker. 1995. Nasal cytokine production in viral acute upper respiratory infection of childhood. J. Infect. Dis. 171:584-592.

8. Calhoun, W.J., E.C. Dick, L.B. Schwartz, and W.W. Busse. 1994. A common cold virus, rhinovirus 16, potentiates airway inflammation after segmental antigen broncho-provocation in allergic subjects. J. Clin. Invest. 94:2200-2208.

9. Elias, J.A., T. Zheng, O. Einarsson, M. Landry, T. Trow, N. Rebert, and J. Panuska. 1994. Epithelial interleukin-11: Regulation by cytokines, respiratory syncytial virus and retinoic acid. J. Biol. Chem. 269:22261-22268.

10. Buckner, C.K., D.E. Clayton, A.A. Ain-Shoka, W.W. Busse, E.C. Dick, and P. Shult. 1981. Parainfluenza 3 infection blocks the ability of a beta-adrenergic receptor agonist to inhibit antigen-induced contraction of guinea-pig isolated airway smooth muscle. J. Clin. Invest. 67:376-384.

11. Sorkness, R., J.J. Clough, W.L. Castleman, and R.F. Lemanske, Jr. 1994. Virus-induced airway obstruction and parasympathetic hyperresponsiveness in adult rats. Am. J. Resp. Crit. Care Med. 150:28-34

12. Dusser, D.J., D.B. Jacoby, T.D. Djokic, I. Rubinstein, D.B. Borson, and J.A. Nadel. 1989. Virus induces airway hyperresponsiveness to tachykinins: role of neutral endopeptidase. J. Appl. Physiol. 67:1504-1511.

13. Neben, S., and K. Turner. 1993. The biology of IL-11. Stem Cells. 11(Suppl 2):156-162.

14. Du, X.X., and D.A. Williams. 1994. Interleukin-11: A multifunctional growth factor derived from the hematopoietic microenvironment. Blood. 83: 2023-2030.

15. Paul, S.R., and P. Schendel. 1992. The cloning and biological characterization of recombinant human interleukin 11. Int. J. Cell Cloning. 10:135-143.

16. Paul, S.R., F. Bennett, J.A. Calvetti, K. Kelleher, C.R. Wood, R.M. O'Hara, Jr., A.C. Leary, B. Sibley, S.C. Clark, D.A. Williams, and Y.-C. Yang. 1990. Molecular cloning of a cDNA encoding IL-11, a stromal cell-derived lymphopoietic cytokine. Proc. Natl. Acad. Sci. USA. 87:7512-7516.

17. Zhang, X.-G., J.-J. Gu, Z.-Y. Lu, K. Yasukawa, G.D. Yancopoulos, K. Turner, M. Shoyab, T. Taga, T. Kishimoto, R. Bataille, and B. Klein. 1994. Ciliary neurotropic factor, interleukin 11 , leukemia inhibitory factor, and oncostatin $\mathrm{M}$ are growth factors for human myeloma cell lines using the interleukin 6 signal transducer GP130. J. Exp. Med. 177:1337-1342.

18. Paul, S.R., B.A. Barut, F. Bennett, M.A. Cochran, and K.C. Anderson. 1992. Lack of a role of interleukin 11 in the growth of multiple myeloma. Leuk. Res. 16:247-252.

19. Elias, J.A., T. Zheng, N.L. Whiting, T.K. Trow, W.W. Merrill, R. Zitnik, P. Ray, and E.M. Alderman. 1994. Interleukin-1 and transforming growth factor $\beta$ regulation of fibroblast-derived interleukin-11. J. Immunol. 152:24212429

20. Zitnik, R.J., and J.A. Elias. 1993. Interleukin-6 in the Lung. In Cytokines of the Lung, in Lung Biology in Health and Disease. C. Lenfant, editor. Marcel Dekker, Inc., New York, NY. 229-280.

21. Marini, M., E. Vittori, J. Hollemborg, and S. Mattoli. 1992. Expression of the potent inflammatory cytokines, granulocyte-macrophage-colony-stimulating factor and interleukin-6 and interleukin-8, in bronchial epithelial cells of patients with asthma. J. Allergy Clin. Immunol. 89:1001-1009.

22. Broide, D.H., M. Lotz, D.A. Coburn, E.C. Federman, and S.I. Wasserman. 1992. Cytokines in symptomatic asthma airways. J. Allergy Clin. Immunol. 89:958-967.

23. Yin, T., P. Schendel, and Y.-C. Yang. 1992. Enhancement of in vitro and in vivo antigen-specific antibody responses by IL-11. J. Exp. Med. 175:211-216.

24. Musashi, M., S.C. Clark, T. Sudo, D.L. Urdal, and M. Ogawa. 1991. Synergistic interactions between interleukin-11 and interleukin-4 in support of proliferation of primitive hematopoietic progenitors of mice. Blood. 78:1448-1451.

25. Lemoli, R.M., M. Fogli, A. Fortuna, M.R. Motta, S. Rizzi, C. Benini, and S. Tura. 1993. Interleukin-11 stimulates the proliferation of human hematopoietic $\mathrm{CD}_{3} 4^{+}$and $\mathrm{CD} 34^{+} \mathrm{CD} 33^{-} \mathrm{DR}^{-}$cells and synergizes with stem cell factor, interleukin-3, and granulocyte-macrophage colony-stimulating factor. Exper. Hematol. 21:1668-1672.

26. Patterson, P.H., and H. Nawa. 1993. Neuronal differentiation factors/ cytokines and synaptic plasticity. Cell 72(Suppl):123-137.

27. Gundel, R.H., G. Letts, and G.J. Gleich. 1991. Human eosinophil major basic protein induces airway constriction and airway hyperresponsiveness in primates. J. Clin. Invest. 87:1470-1473.

28. Barker, R.L., R.H. Gundel, G.J. Gleich, J.L. Checkel, D.A. Loegering, L.R. Pease, and K.J. Hamann. 1991. Acidic polyamino acids inhibit human eosinophil granule major basic protein toxicity. Evidence for a functional role for ProMBP. J. Clin. Invest. 88:798-805.

29. Robinson, D.S., Q. Hamid, S. Ying, A. Tsicopoulos, J. Barkans, A.M. Bentley, C. Corrigan, S.R. Durham, and A.B. Kay. 1992. Predominant $\mathrm{T}_{\mathrm{H} 2}$-like bronchoalveolar T-lymphocyte population in atopic asthma. N. Engl. J. Med. 326:298-304.

30. O'Garra, A., and K. Murphy. 1994. Role of cytokines in determining T-lymphocyte function. Curr. Opin. Immunol. 6:458-466.

31. Spiegelberg, H.L. 1990. The role of interleukin-4 in $\operatorname{IgE}$ and $\operatorname{IgG}$ subclass formation. Semin. Immunopathol 12:365-383.

32. Tsai, M., L.-S. Shih, G.F.J. Newlands, T. Takeishi, K.E. Langley, K.M. Zsebo, H.R.P. Miller, E.N. Geissler, and S.J. Galli. 1991. The rat cKit ligand, stem cell factor, induces the development of connective tissue-type and mucosal mast cells in vivo. Analysis by anatomical distribution, histochemistry, and protease phenotype. J. Exp. Med. 174:125-131.

33. Zheng, T., M. Nathanson, and J.A. Elias. 1994. Histamine augments cytokine-stimulated IL-11 production by human lung fibroblasts. J. Immunol. 153:4742-4752.

34. Rochester, C.L., S.J. Ackerman, T. Zheng, and J.A. Elias. 1994. Major basic protein regulation of cytokine production by human lung fibroblasts. Am. J. Resp. Crit. Care Med. 149:A13 (Abstr.)

35. Hsiung, G.D. C.K.Y. Fong, and M.L. Landry. 1994. Hsiung's Diagnostic Virology. Fourth Edition, Yale University Press, New Haven, CT.

36. Landry, M.L., and G.D. Hsiung. 1994. Diagnostic techniques. Isolation and identification by microscopy. In Encyclopedia of Virology, Academic Press, Limited, London.

37. Martin, T., N. Gerard, S. Galli, and J. Drazen. 1988. Pulmonary responses to bronchoconstrictor agonists in the mouse. J. Appl. Physiol. 64(6) 2318-2323.

38. DiCosmo, B.F., G.G. Geba, D. Picarella, J.A. Elias, J.A. Rankin, B.R. Stripp, J.A. Whitsett, and R.A. Flavell. 1994. Airway targeted interleukin-6 in transgenic mice: Uncoupling of airway inflammation and bronchial hyperreactivity. J. Clin. Invest. 94:2028-2035.

39. Amdur, M.O., and J. Mead. 1958. Mechanics of respiration in unanesthetized guinea pigs. Am. J. Physiol. 192:364-368.

40. Denny, F.W., and W.A. Clyde. 1986. Acute lower respiratory tract infections in non-hospitalized children. J. Pediatr. 108:635-646.

41. Whyte, M.K.B., N.B. Choudry, and P.W. Ind. 1993. Bronchial hyperresponsiveness in patients recovering from acute severe asthma. Respir. Med. 87: 29-35.

42. Pueringer, R.J., and G.W. Hunninghake. 1992. Inflammation and airway reactivity in asthma. Am. J. Med. 92:(6A)32-38.

43. Watson, M.L., D. Smith, A.D. Bourne, R.C. Thompson, and J. Westwick. 1993. Cytokines contribute to airway dysfunction in antigen-challenged guinea pigs: Inhibition of airway hyperreactivity, pulmonary eosinophil accumulation, and tumor necrosis factor generation by pretreatment with an interleukin-1 receptor antagonist. Am. J. Respir. Cell Molec. Biol. 8:365-369.

44. Kips, J.C., J. Tavernier, and R.A. Pauwels. 1992. Tumor necrosis factor causes bronchial hyperresponsiveness in rats. Am. Rev. Resp. Dis. 145:332-336.

45. Van Oosterhout, A.J., A.R. Ladenius, H.F. Savelkoul, I. Van Ark, K.C. Delsman, and F.P. Nijkamp. 1993. Effect of anti-IL-5 and IL-5 on airway hyperreactivity and eosinophils in guinea pigs. Am. Rev. Resp. Dis. 147:548-552.

46. Pretolani, M., and B. Vargaftig. 1993. From lung hypersensitivity to bronchial hyperreactivity. Biochem. Pharmacol. 45:791-800.

47. Swiecichowski, A.L., K.J. Long, M.L. Miller, and G.D. Leikauf. 1993. Formaldehyde-inducing airway hyperreactivity in vivo and ex vivo in guinea pigs. Environ. Res. 61:185-199.

48. Arimura, A., F. Asanuma, H. Yagi, A. Kurosawa, and M. Harada. 1993. Involvement of thromboxane A2 in bronchial hyperresponsiveness but not lung inflammation induced by bacterial LPS in guinea pigs. Eur. J. Pharmacol. 231: $13-21$

49. Brugman, S.M., G.L. Larsen, P.M. Henson, J. Honor, and C.G. Irvin 1993. Increased lower airways responsiveness associated with sinusitis in a rabbit model. Am. Rev. Respir. Dis. 147:314-320.

50. Du, X.X., C.M. Doerschuk, A. Orazi, and D.A. Williams. 1994. A bone marrow stromal-derived growth factor, interleukin-11, stimulates recovery of small intestinal mucosal cells after cytoablative therapy. Blood. 83:33-37.

51. Gottlieb, J.J. 1925. Relation of intranasal disease in the production of bronchial asthma. JAMA. 85:105-107.

52. Nawa, H., S. Nakanishi, and P.H. Patterson. 1991. Recombinant cholinergic differentiation factor (LIF) regulates sympathetic neuron phenotype by alterations in the size and amounts of neuropeptide mRNAs. J. Neurochem. 56: 2147-2150.

53. Tomassini, J.E., D. Graham, C.M. DeWitt, D.W. Lineberger, J.A. Rodkey, and R.J. Colonno. 1989. cDNA cloning reveals that the major group rhinovirus receptor on HeLa cells is intercellular adhesion molecule 1. Proc. Natl. Acad. Sci. USA. 86:4907-4911.

54. Hofer, F., M. Gruenberger, H. Kowalski, H. Machat, M, Huettinger, E. Kuechler, and D. Blaas. 1994. Members of the low density lipoprotein receptor family mediate cell entry of a minor-group common cold virus. Proc. Natl. Acad. Sci. USA. 91:1839-1842.

55. Elias, J.A., R. Zitnik, and P. Ray. 1992. Fibroblast Immune-Effector Function. In Pulmonary Fibroblast Heterogeneity. R. Phipps, editor. CRC Press, Boca Raton, FL. 295-322. 